after the war. He contended that federal involvement continued into the postwar years despite the apparent hegemony of Vannevar Bush's approach, which emphasized control by the private sector. Allen Kaufman (University of New Hampshire) argued that the roots of the militaryindustrial complex were laid during the war because of the enormous effectiveness of the contract system and the power of military procurement officers in obtaining sufficient coordination among private firms to produce armaments and other material for the war effort.

The final session shifted the discussion to the war's influence on postwar culture. During the break preceding the panel, Tim Berg (Indiana University) piqued the audience's interest in his paper by playing recordings of music by musicians such as Chuck Berry, who had first recorded with Chess Records. His paper explained that the postwar success of Chess and other small record labels reflected the combined impact of black migration to cities during the war, the technological advances of cheaper recording equipment and the $45 \mathrm{rpm}$ record, and the capacity of small record companies to cater to the tastes of particular groups. Elizabeth Hillman (US Air Force Academy), contrasted "dress blues" of women in the military during World War Two, which combined attractiveness with utility, to the promotion of frivolous dresses after the war, which emphasized female attractiveness and domesticity at the expense of career. Jeffrey Meikle (University of Texas) demonstrated how the wartime development of new plastics allowed manufacturers to promote postwar plastic consumer products as both visually pleasing and easy to clean-what he dubbed "damp cloth utopianism."

A particularly refreshing aspect of the conference was the interaction among scholars based in different disciplines but all interested in the tremendous impact of World War Two on the immediate postwar period. While there are no plans to publish the conference proceedings, doubtless many of these papers will appear in academic journals in the next few years.

\title{
International Congress for Historians
}

\author{
Adelheid von Saldern
}

Universität Hannover

This meeting, held in Montreal (August 27-September 3, 1995) foregrounded sessions on "major themes" like "nations, peoples, and state 
forms," "gender," and "peoples in diasporas" while devoting only a few sessions to labor and working-class movements-and these were secondary roundtables.

A session led by Janusz Zarnowski on "The Political Role of the Working-Class: Myth and Reality" was stimulated by the political events of 1989-1990. The participants chose to examine and interpret this as a purely historical subject, excluding discussion of future political roles for Marxism. Those expecting sophisticated comparisons and comprehensive theses may have been disappointed. However, the papers covered many countries and presented a number of useful insights on long-term processes. In his comparison of Great Britain and the United States, Neville Kirk emphasized the differences between their political systems and their processes of proletarianization. Citizenship, federalism, republicanism, and suffragethe most important components of the American political systeminfluenced the way proletarianization was interpreted, while proletarianization itself was also characterized by deep-reaching ethnic fragmentation.

Klaus Tenfelde argued that German social democracy developed in peculiar contrast to Great Britain, the United States, and other Western countries. The German working-class movement, he maintained, was shaped by its latent development toward a leftist "people's party" as in the Western countries, but in practice was hindered from pursuing such a "normal" path by its opponents, the state and the influential upper classes, especially during the Kaiserreich. At first sight this appears to be convincing. A consequence of this argument, however, is that utopian socialism, the radical wing, and later on the communist movement have dropped out of the historiography (which was indeed the case in this paper), or have been marginalized as reactions to suppression instead of being credited as forms of socialism with their own creative visions.

Diana Quattrocchi-Woisson's paper on Latin America focused on trade unions' paths through the nineteenth and twentieth centuries. Anarchism, nationalism, autonomy, populist movements (e.g., Peronism), the absence of class consciousness, and the influential role of the state were some of the special features influencing the working-class movements in these countries. Since states controlled these national economies, workingclass movements regarded the state as a "partner" as well as an opponent.

Remarkably, these papers did not integrate methodological problems into their reinterpretations of working-class movements-like the social construction of the "working class" and considerations of the impact of "myths" on "reality." Such methodological considerations were clearly present, however, in a session led by Roger Chartier on the construction of social identities. Chartier, focusing on recent changes in social history, stressed the end of the idea of stable and uniform classes, the importance of language and symbols in the definition of social situations and relations, and the extension of the "social world" to local communities, small groups, 
and families. Jürgen Kocka proposed that analyses of the working class should be carried out on three levels: structures and processes; collective consciousness and "habitus"; and collective action. Kocka endorsed the themes of representation, language, and strategy as new opportunities for more subtle and more precise research, but also pointed to dangers: an extreme linguistic turn, an overemphasis of the impact of symbols, and a neglect of "social reality."

Rebecca Scott's comparison of blacks in postemancipation Cuba and Louisiana was thought-provoking. In Louisiana former slaves wanted land of their own, and when this ambition could not be realized, they resisted a social identity as waged workers. As a consequence, it was also difficult to develop and maintain a social identity as citizens. The situation in Cuba was quite different. After the end of slavery, race was a less prominent issue, and a multiethnic process of social identification followed. Although racial tensions continued, black workers were able to identify more or less as "patriots" of their country.

"Beyond Social Democracy: Comparative Radical Working-Class Movements, 1914-1939" was the subject of a roundtable led by William A. Pelz. This session attracted attention because some of the research presented was drawn from the newly opened (though still restricted) Moscow archives. Leon Trotsky was the center of consideration for two papers. Pierre Broué argued that Trotskyism had strong roots in the Russian and international labor movements, and Alexandre Pantsov stressed that Trotsky's influence extended to China between 1919 and 1922.

While some papers dealt with strong Communist parties, as in Germany, others described smaller radical organizations. For example, F.M. Cain's paper discussed the Industrial Workers of the World (IWW) in Australia - a place which has often been overlooked in the historiography of radicalism. During World War One this small but radical organization tried to transfer its antimilitarism to the labor movement, which finally led to its prohibition by the government.

Brigitte Studer presented a methodologically interesting paper on the tiny Communist party in Switzerland. She concentrated on a cultural explanation of communists' social identification with the Comintern. More than a political organization, she concluded, the Comintern was a frame of reference for the Swiss communists' everyday world.

The contrast between the reformist social democracy discussed by one panel and the radical communists discussed by another was striking. One is prompted to ask whether, six years after 1989, the time has not come to heal this traditional division and to examine the common contexts of reformism and radicalism among workers and intellectuals. Likewise, has the time not come to extend consideration of workers' social identities (as accomplished by Chartier's panel) to "normal" working-class historiography? 